\title{
Diagnostic distinction between anencephaly and amnion rupture sequence based on skeletal analysis
}

\author{
Jean W Keeling, Inger Kjær
}

Royal Hospital for Sick Children, Edinburgh, UK J W Keeling

\section{Department of} Orthodontics, School of Dentistry, Faculty of Health Sciences, University of Copenhagen 20 Nørre Allé, DK2200 Copenhagen N, Denmark

I Kjær

Correspondence to Dr Kjær.

Received 2 June 1994 Accepted for publication 6 July 1994
Abstract

The axial skeletal development of eight second trimester aborted fetuses, clinically diagnosed as amnion rupture sequence with cranial involvement, was examined radiographically and histologically. Three of the eight fetuses showed axial skeletal malformation in the spine and the craniofacial skeleton corresponding to the malformations seen in anencephaly. These are vertebral body malformations, consisting of double corpora and of osseous malformations in the components of the cranial base, the corpus of the occipital bone, and the postsphenoid bone. These types of malformation, which have previously been described, are located along the original course of the notochord.

The findings show that it is possible by means of radiography of the axial skeleton to distinguish between anencephalic fetuses which become secondarily involved in amnion rupture and fetuses which were initially normally developed. The method supplements detailed fetal examination and provides important information for genetic counselling.

\section{( $\mathcal{}$ Med Genet 1994;31:823-829)}

The amniotic band disruption complex or early amnion rupture sequence is characterised by a variety of combinations of fetal disruption, often involving different body regions, which are usually asymmetrical. Tissue bands, sometimes running to the placental membranes are often, but not universally, observed particularly in the more mature fetus. A disrupted fetal part may be firmly adherent to placental membranes over a wide area. ${ }^{1-4}$

Theories about the aetiology and pathogenesis of this sequence are many and are discussed later. They do, however, underlie a major diagnostic problem, particularly when the cephalic region is involved. Seeds et $a l^{5}$ drew attention to misdiagnosis and inappropriate counselling and mentioned cranial defects as a potential source of confusion. Hughes and Benzie ${ }^{6}$ and Urich and Herrick cited amnion disruption as a cause of anen-

Types of anomaly seen in amnion rupture sequence

\begin{tabular}{|c|c|c|c|c|c|c|c|c|c|}
\hline \multirow[t]{2}{*}{ Fetuses* } & \multirow[t]{2}{*}{$G A$} & \multirow{2}{*}{$\begin{array}{l}\text { Fig } \\
\text { No }\end{array}$} & \multicolumn{4}{|c|}{ Postmortem external examination } & \multicolumn{2}{|c|}{ Postmortem axial radiography } & \multirow[t]{2}{*}{ Diagnosis } \\
\hline & & & Craniofacial & Trunk & Limbs & Amniotic band & Cranial base & Vertebral bodies & \\
\hline $\begin{array}{l}\text { Case } 1 \\
\text { Case } 2\end{array}$ & $\begin{array}{l}22 \\
17\end{array}$ & $\begin{array}{l}9 \\
8\end{array}$ & $\begin{array}{l}\text { Meracrania, as } \\
\text { Meracrania, as } \\
\text { Abnormal facial } \\
\text { clefts, as } \\
\text { Eye malf, as }\end{array}$ & $\begin{array}{l}\text { Normal } \\
\text { Normal }\end{array}$ & $\begin{array}{l}\text { Bilateral talipes } \\
\text { Small short } \\
\text { fingers, as } \\
\text { Toes curled up, } \\
\text { as } \\
\text { Vestigial big toe, } \\
\text { as }\end{array}$ & $\begin{array}{l}\text { Head } \\
\text { Hands, feet }\end{array}$ & $\begin{array}{l}\text { Normal, s } \\
\text { Malformed } \\
\text { sphenoid corpus } \\
\text { (not anenceph } \\
\text { type), s }\end{array}$ & $\begin{array}{l}\text { Normal, s } \\
\text { Normal, s }\end{array}$ & $\begin{array}{l}\text { ARS } \\
\text { ARS }\end{array}$ \\
\hline Case 3 & 15 & 1,3 & $\begin{array}{l}\text { Holocrania, facial } \\
\text { cleft, ear, eye, } \\
\text { as }\end{array}$ & Imperforate anus & $\begin{array}{l}\text { Right arm absent } \\
\text { Right leg red, } \\
\text { left white }\end{array}$ & Not seen & $\begin{array}{l}\text { Malformed } \\
\text { (anenceph type), } \\
\text { as and s }\end{array}$ & $\begin{array}{l}\text { Double vertebral } \\
\text { bodies } \\
\text { (anenceph type), } \\
\text { as and s }\end{array}$ & $\begin{array}{l}\text { Anencephaly } \\
\text { and ARS }\end{array}$ \\
\hline Case 4 & 18 & $4 A, 5$ & Meracrania, as & $\begin{array}{l}\text { Kyphoscoliosis } \\
\text { Abdominal } \\
\text { wall defect }\end{array}$ & $\begin{array}{l}\text { Vestigial right arm } \\
\text { Deformed lower } \\
\text { limbs, as }\end{array}$ & Head, abdomen & Normal, s & $\begin{array}{l}\text { Normal, s but } \\
\text { torqued }\end{array}$ & ARS \\
\hline $\begin{array}{l}\text { Case } 5 \\
\text { Case } 6\end{array}$ & $\begin{array}{l}14 \\
17\end{array}$ & $4 B, 6$ & $\begin{array}{l}\text { Meracrania, s } \\
\text { Anencephalic } \\
\text { facies, } \\
\text { protuberant } \\
\text { orbits, } s\end{array}$ & $\begin{array}{l}\text { Normal } \\
\text { Thoracic } \\
\text { rachischisis } \\
\text { Abdominal wall } \\
\text { defect }\end{array}$ & $\begin{array}{l}\text { Normal } \\
\text { Bilateral talipes }\end{array}$ & $\begin{array}{l}\text { Vertex } \\
\text { Head, abdomen }\end{array}$ & $\begin{array}{l}\text { Normal, s } \\
\text { Malformed } \\
\text { (anenceph } \\
\text { type), s }\end{array}$ & $\begin{array}{l}\text { Normal, s } \\
\text { Double vertebral } \\
\text { bodies } \\
\text { (anenceph type), } \\
\text { s, but torqued }\end{array}$ & $\begin{array}{l}\text { ARS } \\
\text { Anencephaly } \\
\text { and ARS }\end{array}$ \\
\hline Case 7 & 16 & $4 C, 7$ & Holocrania, s & $\begin{array}{l}\text { Thoracolumbar } \\
\text { rachischisis } \\
\text { Omphalocele }\end{array}$ & Normal & Abdomen & $\begin{array}{l}\text { Malformed } \\
\text { (anenceph } \\
\text { type), s }\end{array}$ & $\begin{array}{l}\text { Double vertebral } \\
\text { bodies } \\
\text { (anenceph type), } \\
\text { s, but torqued }\end{array}$ & $\begin{array}{c}\text { Anencephaly } \\
\text { and ARS }\end{array}$ \\
\hline Case 8 & 16 & & Holocrania, as & $\begin{array}{l}\text { Abdominal wall } \\
\text { defect }\end{array}$ & $\begin{array}{l}\text { Amputations and } \\
\text { deformities of } \\
\text { extremities }\end{array}$ & $\begin{array}{l}\text { Hands, feet, } \\
\text { abdominal wall }\end{array}$ & $\begin{array}{l}\text { Malformed } \\
\text { sphenoid corpus } \\
\text { (not anenceph } \\
\text { type), s }\end{array}$ & $\begin{array}{l}\text { Normal, s but } \\
\text { torqued }\end{array}$ & ARS \\
\hline
\end{tabular}

\footnotetext{
${ }^{*}$ Fetuses are listed chronologically. GA = gestational age (wk). ARS = amnion rupture sequence. $\mathrm{s}=$ symmetry; as $=$ asymmetry.
} 


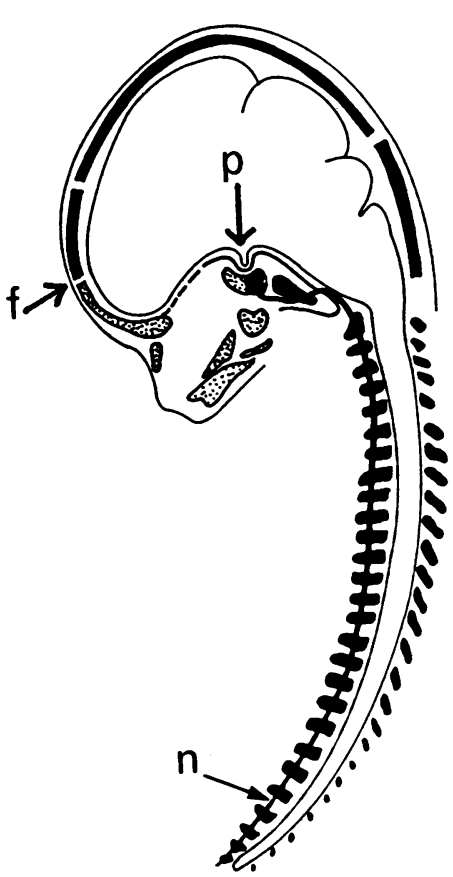

Figure 1 Schematic drawing indicating the axial skeleton and the central nervous system in a midsagittal tissue block from a normal human fetus (14-16 weeks' gestation). The vertical arrow, $p$, indicates the pituitary gland in the sella turcica, and the oblique arrow, $f$, the central area in the frontal bone. Arrow $n$ indicates the original course of the notochord. Solid black areas show the para-axially derived skeleton involved in anencephalic malformation. " Dotted bones show the neural crest derived skeleton, sometimes malformed in anencephaly. ${ }^{10}$

(A)
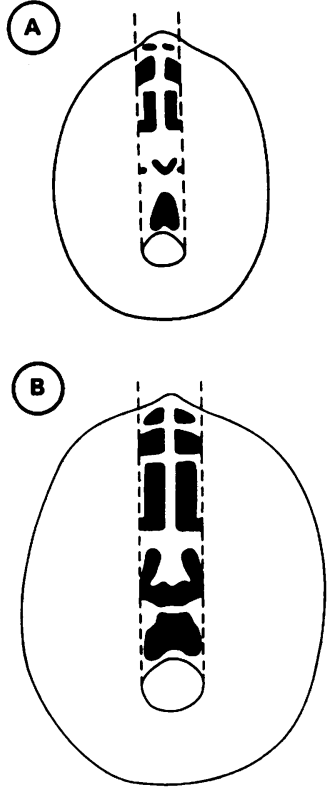

V
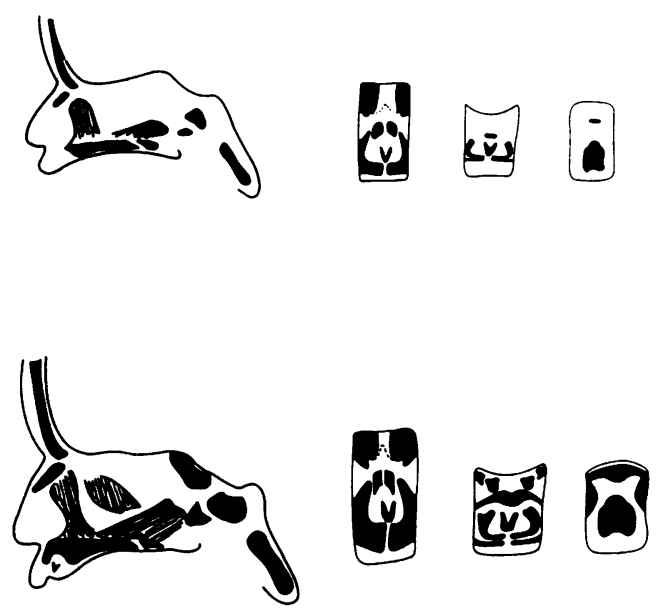

Figure 2 Drawings of radiographs of the midline craniofacial bones in two normal fetuses at different states of skeletal development. Stage $A$ corresponds to 14 to 16 weeks gestation and stage $B$ to 16 to 23 weeks. $V=v e r t i c a l$ projection. $L=$ lateral projection. $F a, F m$, and $F p=$ frontal projections of anterior, middle, and posterior parts of the midsagittal tissue segment, respectively.

cephaly and pointed out the implications for counselling. Goldstein and Filly ${ }^{8}$ stressed the symmetry of the ultrasound abnormality in anencephaly as an important diagnostic feature of primary neural tube defect, but as distinction may be very difficult ${ }^{9}$ detailed fetal examination should always be performed after termination for fetal anomaly.
In our experience, doubt about the distinction between primary defects of cranial neural tube closure which subsequently adhere to the placental amnion and defects owing to subsequent disruption of the normally closed cranial portion of the neural tube may persist even after detailed fetal examination.

The purpose of the present investigation is to analyse the axial skeleton, comprising the spine and the craniofacial skeleton, in a group of fetuses clinically diagnosed as amnion rupture sequence, by comparing the findings to normal skeletal patterns and to skeletal patterns recently described in a group of anencephalic fetuses. ${ }^{1011}$ The axial skeletons in anencephaly showed characteristic malformations along the original course of the notochord, which involve the vertebral bodies, the basilar part of the occipital bone, and the postsphenoid bone, supporting the pituitary gland. Four types of radiographical and histological craniofacial de-

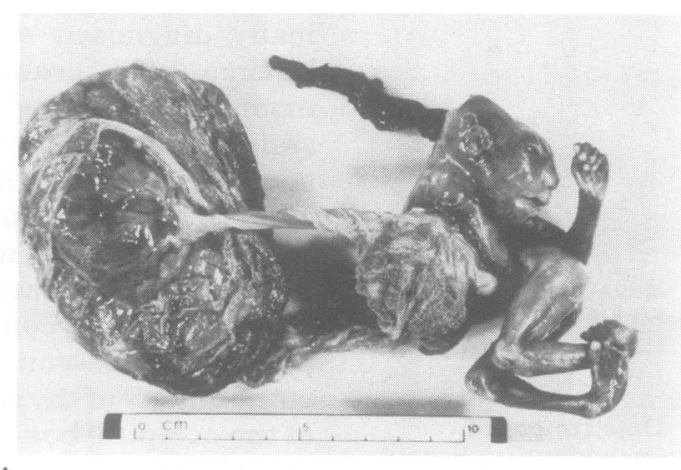

$B$
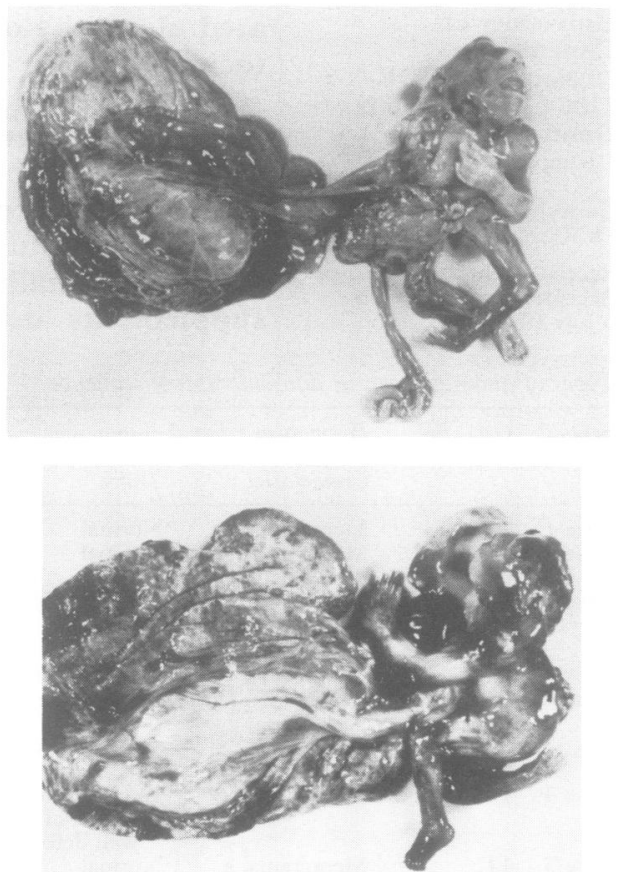

Figure 3 Three human fetuses with placenta. Clinical diagnoses of fetuses: amnion rupture sequence. $(A)$

Gestational age 18 weeks. For radiographic examination, see fig 5. (B) Gestational age 17 weeks. For radiographic see fig 5. (B) Gestational age 17 weeks. For radiographic
examination, see fig 6 . (C) Gestational age 16 weeks. For radiographic examination, see fig 7 . The external clinical characteristics of the three fetuses do not permit distinction between fetuses originally affected by anencephaly and secondarily by amnion rupture sequence and fetuses only affected by amnion rupture sequence. 

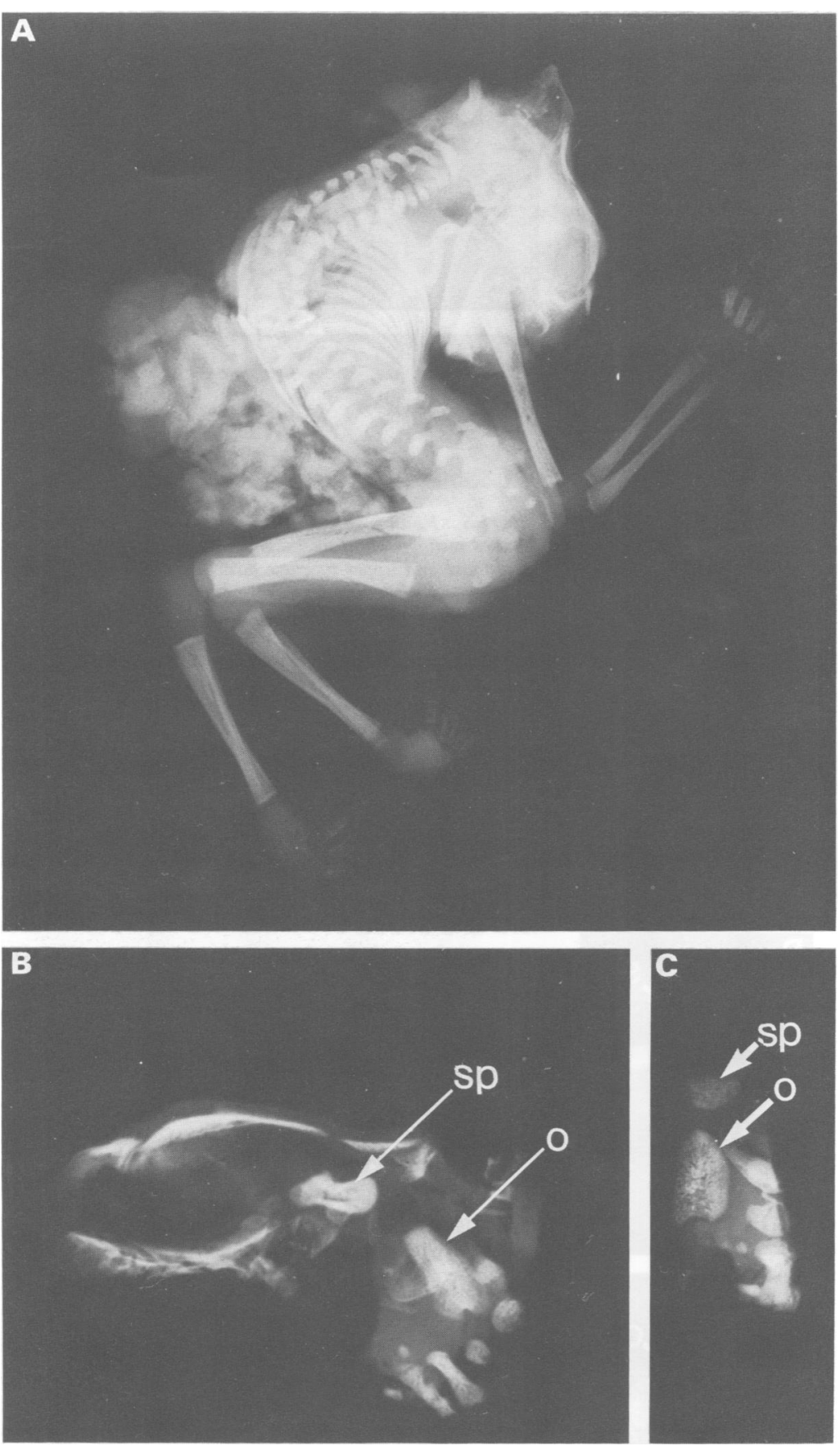

Figure 4 Radiographs of fetus shown in fig $3 A$. (A) Whole body radiograph. (B) Lateral radiograph of midsagittal cranial structures showing normal structures of the basilar part of the occipital bone (o) and of the postsphenoid bone component (sp). (C) Frontal radiograph of posterior cranial base segment ( $F p$ segment) indicating occipital and sphenoid bone components, same as in (B). The radiographs show normal spine contour with a pronounced curvature and normal cranial base bony component, indicating a normal fetus affected by amnion rupture sequence.

viations in anencephaly have previously been described. ${ }^{11}$ These are deformed/normal contours, cleft palate, short nasal septum, and multilocular ethmoid cartilage malformation. The goal is to assess the validity of skeletal investigations as a contribution to the improvement of genetic counselling in amnion rupture sequence.

\section{Material and methods} FETUSES

The series comprised eight human fetuses with diagnosed amion rupture sequence from legally approved therapeutic abortions. The fetuses were derived from a consecutive series of aborted fetuses examined during 1987 to 1989 at the Department of Histopathology, John Radcliffe Hospital, Oxford, UK. The main data concerning age and necropsy are shown in the table. Foot lengths were between 14 and $39 \mathrm{~mm}$, corresponding to gestational ages between approximately 14 and 22 weeks.

From the time of routine diagnostic examination until the present investigation, the fetuses were kept fixed in $10 \%$ buffered formalin.

\section{RADIOGRAPHY}

Whole body radiographs in frontal and lateral projections were first taken. Tissue was then dissected for further radiological analysis. This included a midsagittal tissue block of the cranium and the entire spine (fig 1). The sectioning was done from the interior side of the cranial base by letting two sagittal incisions touch the lateral borders of the foramen magnum. The incisions continued on both sides of the often extremely curved and torqued spine to the very caudal end. The interjacent midsagittal segment was radiographed in frontal and lateral projections before and after being stretched out.

The midsagittal tissue block of the cranial base was separated from the spine and divided by means of two frontal sections into three parts of equal fronto-occipital dimensions: anterior $(\mathrm{Fa})$, middle $(\mathrm{Fm})$, and posterior $(\mathrm{Fp})$. These blocks were examined in lateral and frontal projection (fig 2). The following distinctions were made: notochordal axial skeleton: the vertebral bodies of the spine and the Fp segment, constituting the axial skeleton posterior to the sella turcica; craniofacial skeleton: $\mathrm{Fa}$ and Fm segment, constituting the axial skeleton anterior to the sella turcica.

A Grenz ray radiographic apparatus, Hewlett Packard, Faxitron Series $43805 \mathrm{~N} x$ ray system was used with Kodak X-Omat film. The tissue was placed directly on the film envelope. Depending on the size of the specimen, the tube voltage varied between 20 and $60 \mathrm{kV}$, and the exposure time from 10 to 60 seconds at $2 \cdot 8$ to $3.0 \mathrm{~mA}$.

From the radiographs, enlarged paper copies and drawings of the ossified tissue were made and used for the detailed analysis. Similar radiographs and outline drawings from a series of normal fetuses with corresponding gestational age, foot length, and general skeletal development (assessed by counting the number of ossified bones in hand and foot ${ }^{12}$ ) were used as controls. ${ }^{13}$ Two normal developmental stages in the spine ${ }^{14}$ and two stages in the cranial base and craniofacial skeleton ${ }^{15-19}$ covered the material under study.

\section{HISTOLOGY}

After radiography, the $\mathrm{Fa}$ and $\mathrm{Fm}$ tissue blocks were embedded in paraffin, cut frontally into $5 \mu \mathrm{m}$ sections, and stained with toluidine blue at $\mathrm{pH}$. Tissue from a series of normal fetuses of corresponding gestational age was used for control purposes. 

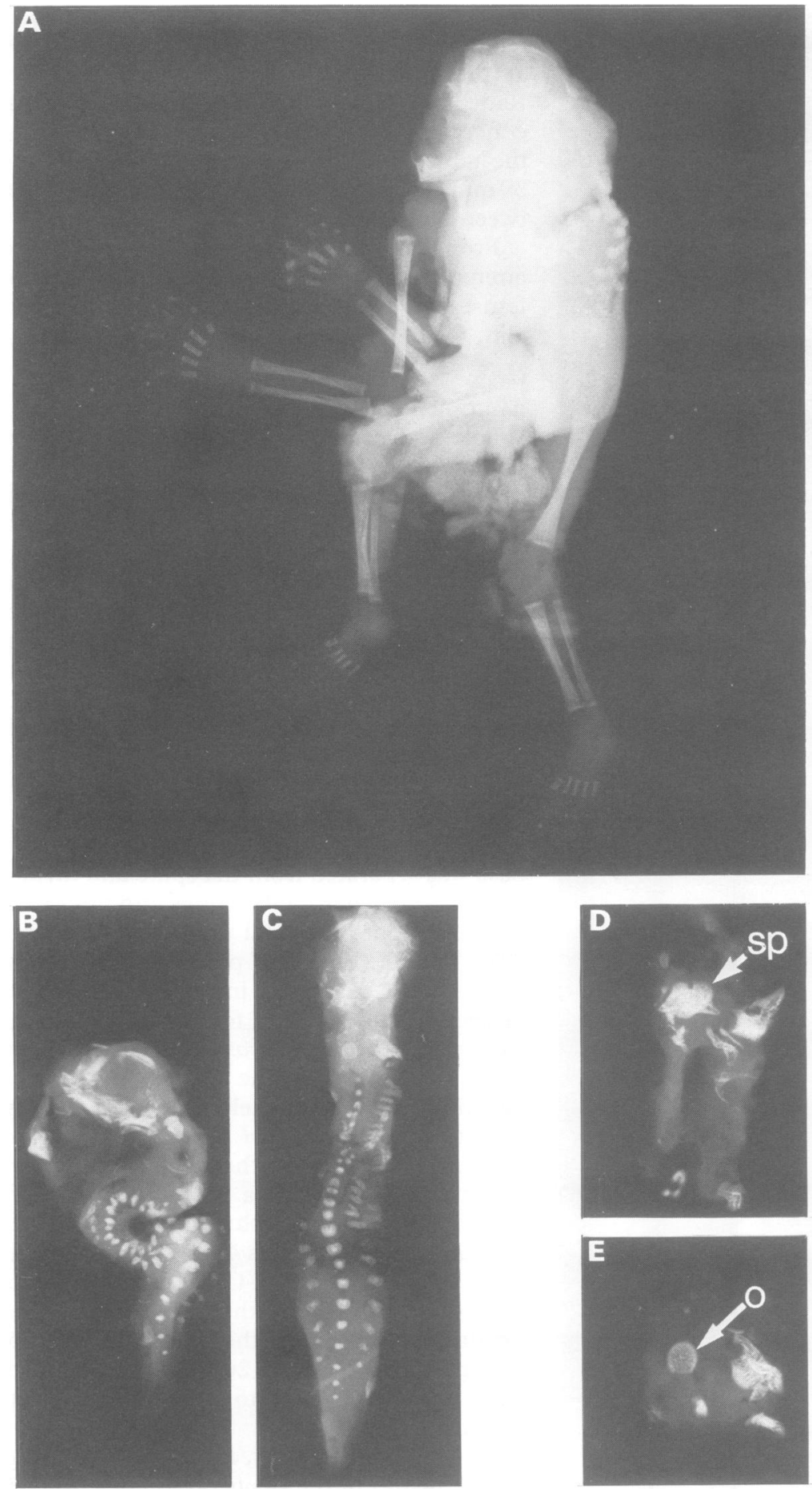

Figure 5 Radiographs of fetus shown in fig 3B. (A) Lateral radiograph of the whole body. (B) Lateral radiograph of midsagittal axial tissue segment including the spine and cranial components. (C) Frontal radiograph of stretched spine and cranial base midsagittal segment showing double vertebral bodies in the cervical and upper thoracic regions. (D), (E) Frontal radiographs of tissue segments from the midsagittal cranial base showing the postsphenoid bone component (sp) and the basilar part of the occipital bone (o). Both bony structures are malformed. The spine and the bony contours in the cranial base indicate that the fetus is presumably anencephalic, secondarily affected by amnion rupture sequence.
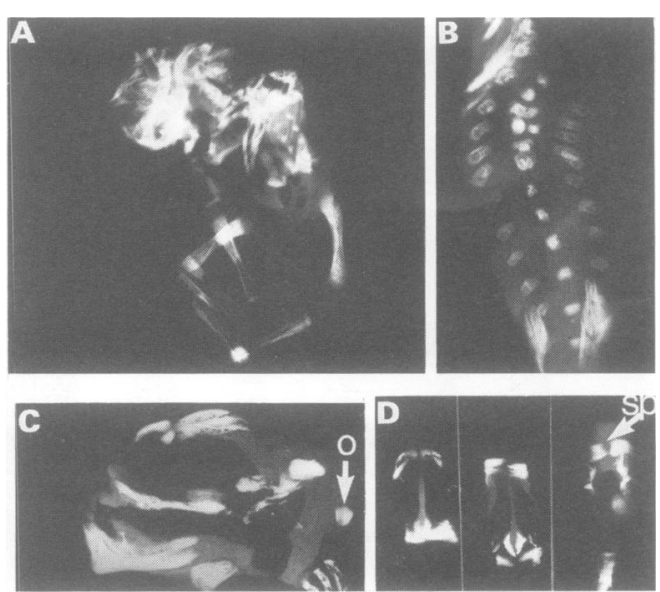

Figure 6 Radiographs of fetus shown in fig 3C. (A)

Lateral radiograph of whole body. (B) Frontal radiograph of cervical and upper thoracic part of the spine indicating the existence of double vertebral bodies. (C) Lateral radiograph of midsagittal cranial structures indicating malformed basilar part of occipital bone (o). (D) Frontal radiographs of anterior, middle, and posterior segments of the midsagittal craniofacial segment indicating normal bony contours in front of the malformed sphenoid body (sp). The spine and the bony contours in the cranial base indicate that the fetus is presumably anencephalic, secondarily affected by amnion rupture sequence.

\section{NOTOCHORDAL AXIAL SKELETON}

It was a characteristic finding in the three fetuses with an anencephalic ossification pattern that double or malformed vertebral bodies occurred in the spine and, corresponding to this pattern in the spine, the basilar parts of the occipital bone (Fp segment) are short in the craniocaudal dimension. In all three cases malformations were also seen in the region of the rostral end of the notochord, in postsphenoid bone, supporting the pituitary gland.

The five fetuses without an anencephalic ossification pattern showed a normal ossification pattern in the spine, as illustrated in figs 4 and 9, and a normal appearance of the basilar part of the occipital bone (Fp segment), illustrated in figs 4,9 , and 10 . The postsphenoid bone appeared normal in two cases (figs 4 and 10) and had a horseshoe shape, open anteriorly, in one case (fig 9). This type of malformation was never observed in anencephaly.

The five fetuses not showing anencephalic malformations in the spinal skeleton, often showed severely distorted spines (fig 8).

\section{CRANIOFACIAL SKELETON}

In five cases external asymmetry of the craniofacial structures was recorded. Three cases appeared to be symmetrical in external craniofacial appearance. In the present investigation one of the three fetuses with an anencephalic axial ossification pattern showed asymmetrical multilocular ethmoid cartilage (fig 8), and the remaining fetuses showed symmetrical craniofacial skeletal morphology though disrupted contours.

The cleft in the palate and lip of one fetus (fig 9) was a mucosa covered, midsagittally located furrow, seemingly caused by distortion. There was no resemblance to developmentally related cleft lip, which occurs parasagittally, and 8 . 

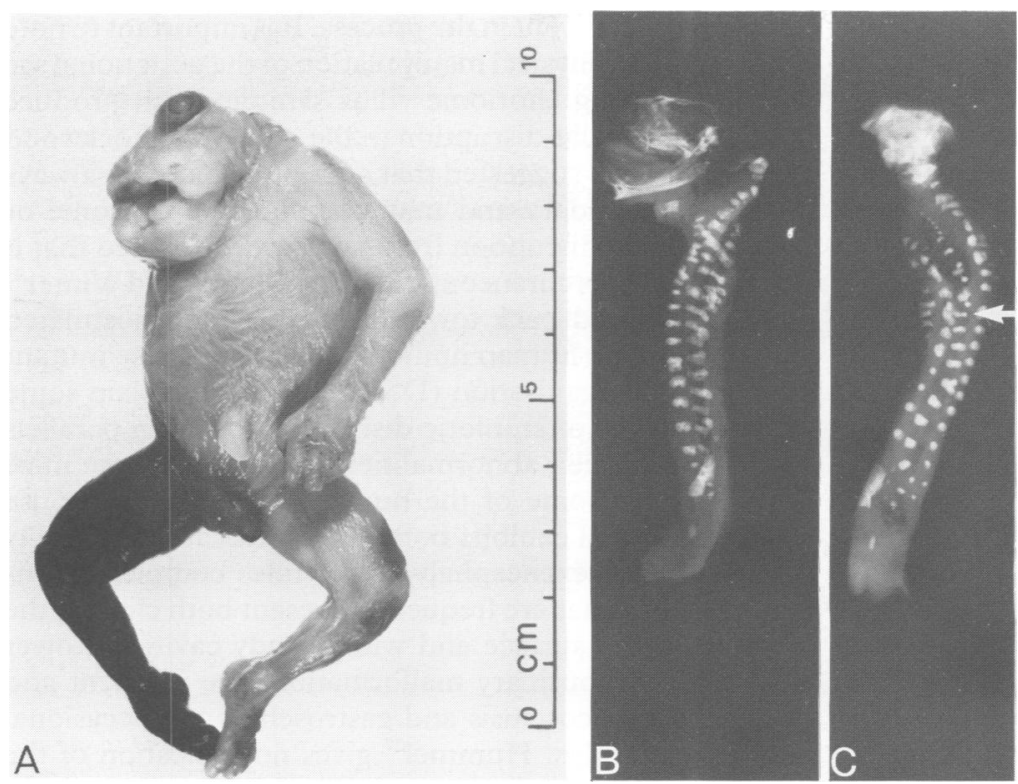

Figure 7 (A) Human fetus clinically diagnosed as amnion rupture sequence. Gestational age 15 weeks. (B) Lateral radiograph of axial midsagittal tissue segment including the spine and cranial components, including the mandible. (C) Frontal radiograph of tissue segment illustrated in $B$ after removal of the mandible. Radiographic examination shows vertebral body alterations (double bodies arrowed) which correspond to the changes seen in anencephaly with open cranioschisis involving the cervical region. The fetus thus appears to be primarily an anencephalic fetus, which has secondarily been affected by amnion rupture sequence. or to cleft palate, which does not occur with mucosal coverage along the entire midline of the maxilla.

To summarise, three of the eight fetuses clinically diagnosed as amnion rupture sequence showed all the signs in the axial skeleton of being originally anencephalic, with skeletal disturbances close to the early location of the notochord. It can thus be concluded that the method of skeletal mapping based on radiography enabled the fetal material to be subgrouped accordingly, while external clinical characteristics, such as symmetry and asymmetry, did not show agreement with the radiographic findings as regards the groups. It is obvious that a primarily anencephalic fetus secondarily involved in amnion rupture sequence can appear asymmetrical, similar to the fetuses primarily involved in amnion rupture sequence.

As the pattern of skeletal malformation in the three fetuses with skeletal anencephalic appearance is identical to the pattern formerly described along the course of the early notochord in anencephaly, it is presumed that these three fetuses were originally anencephalic, which predisposed to amniotic adhesion. Detailed studies of the skeletal
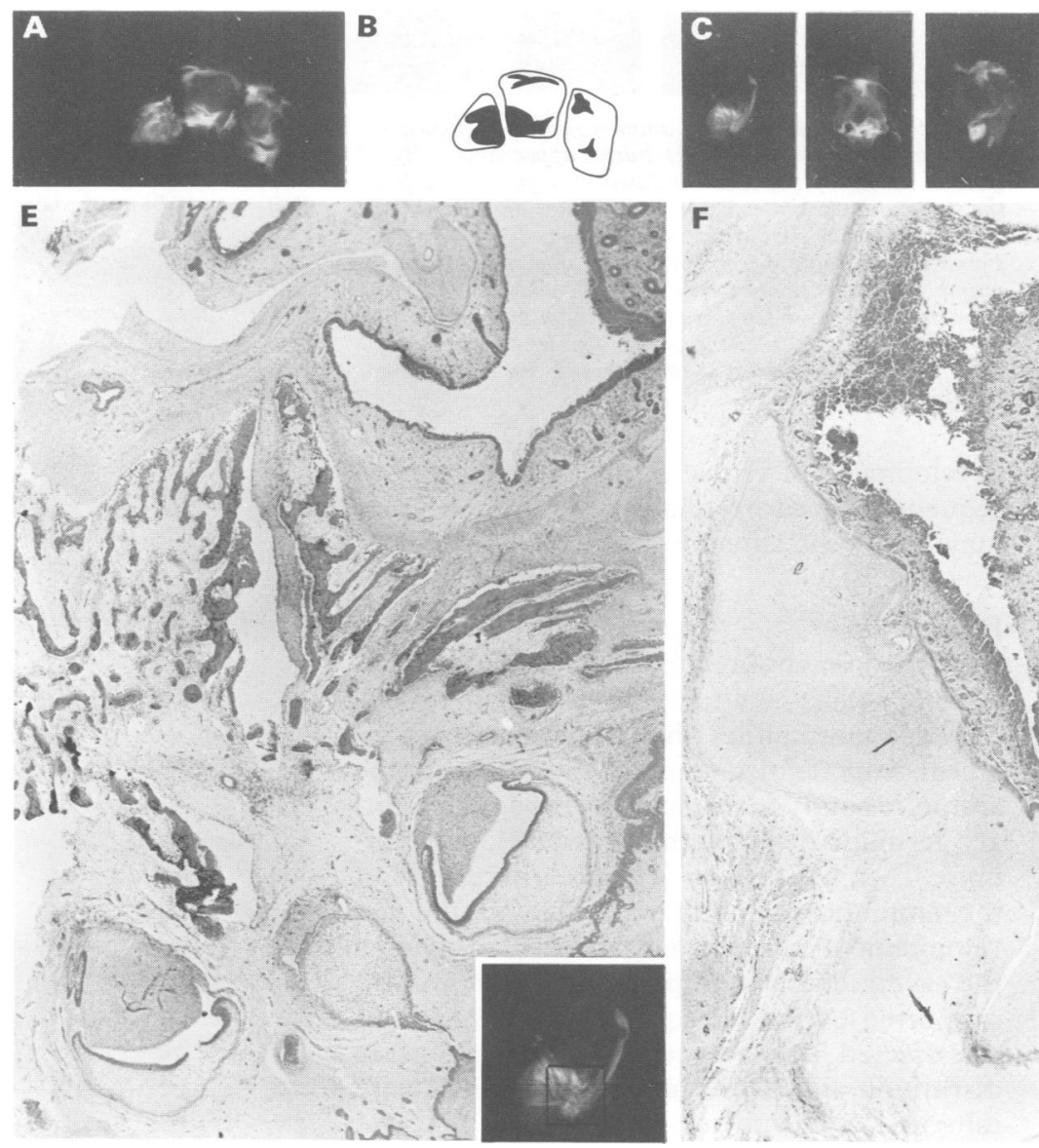

D

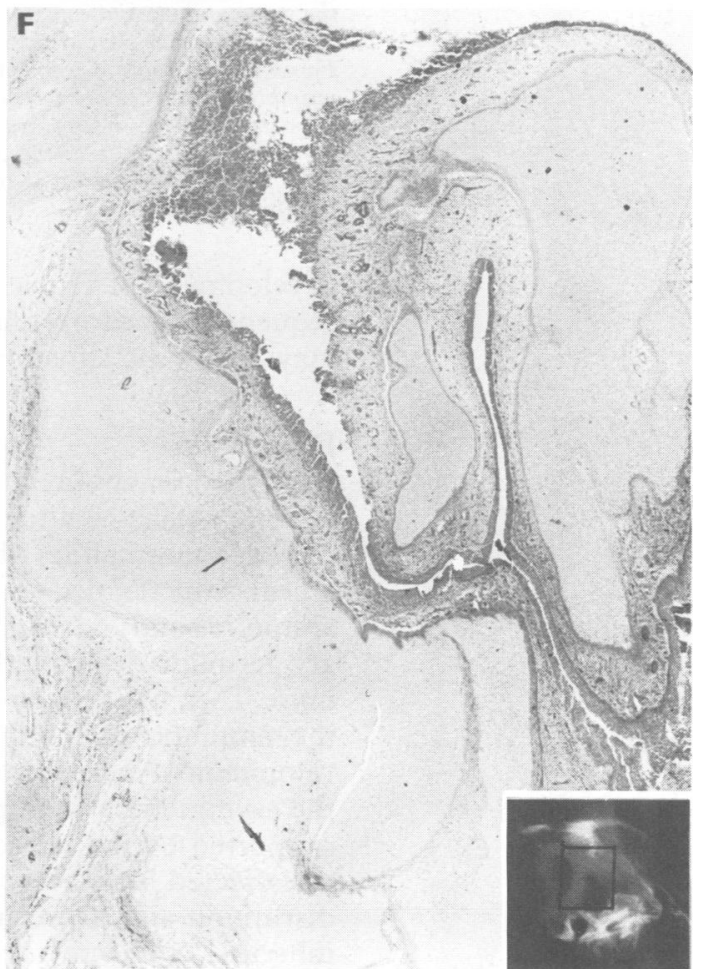

Figure 8 Craniofacial analysis of same fetus as shown in fig 7. (A), (B) Lateral radiographs and drawings of the midsagittal anterior, medial, and posterior segments of the craniofacial block. (C), (D) Frontal radiographs and drawings of the anterior, medial and posterior segments of the midsagittal craniofacial block. $(E),(F)$ Frontal histological sections of the midsagittal craniofacial tissue blocks of the anterior segment $(E)$ and middle segment $(F)$. The frame on the inserted radiographs (Fa and Fm segments, same as $C$ and D) indicates the microscopic field. (Toluidine blue, pH7.) Craniofacial skeleton malformed and asymmetrical. Conglomerate of maxillary bone tissue and asymmetrical tooth anlage occurs in the palate $(E)$ and multilocular ethmoid cartilage with several small irregular spaces covered with epithelium appears in the nasal cavity $(F)$. 

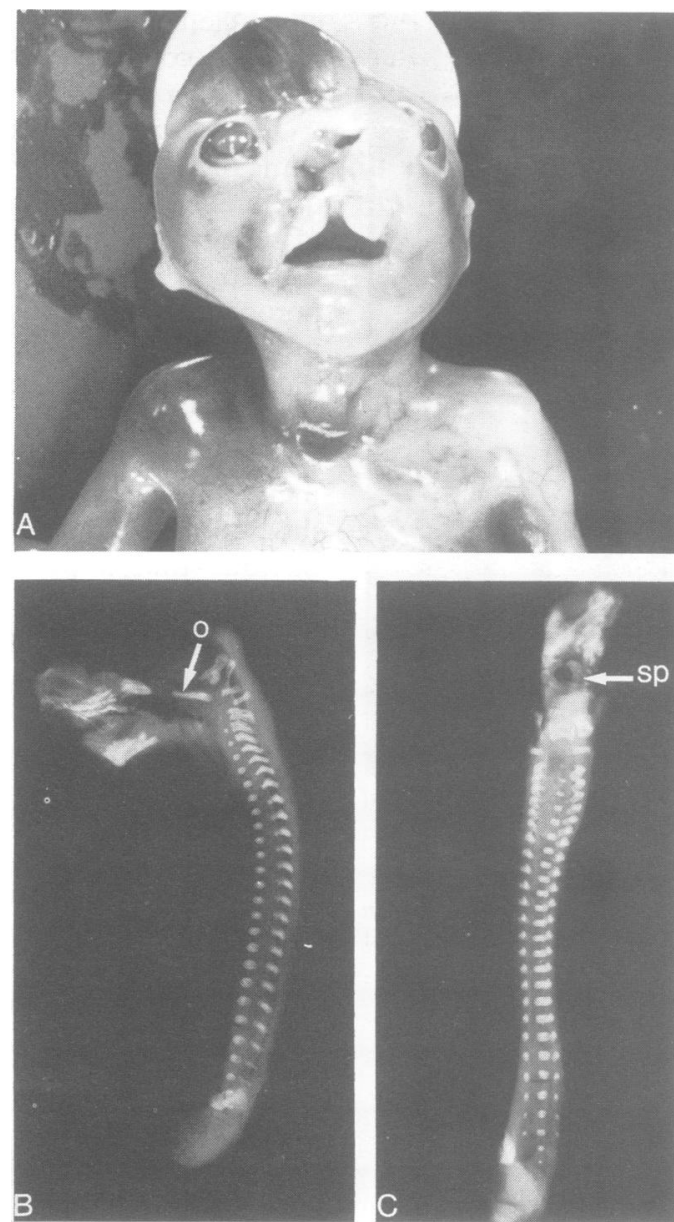

Figure 9 Human fetus with amnion rupture sequence. Gestational age 17 weeks. (A) Facial appearance. (B) Lateral radiograph of axial midsagittal segment including the spine and cranial components. Normal appearance of spine and basilar part of the occipital bone (o). (C) Frontal radiograph of segment in (B) after removal of the mandible. The posterior part of the sphenoid bone ( $s p$ ) appears horseshoe shaped, a malformation pattern not normally occurring in anencephaly. The fetus appears to be a normal human fetus secondarily affected by amnion rupture sequence.

development of fetuses with amnion rupture sequence, based on a larger number of cases, may clarify the situation further.

\section{Discussion}

Early theories about the pathogenesis of amnion rupture sequence attempted to explain all observed abnormalities through a single mechanism. Streeter ${ }^{1}$ discounted a causal role for the amniotic bands or strings and proposed a primary germline defect within the developing embryo. Torpin ${ }^{2}$ considered that early rupture of the amniotic membrane resulted in the development of mesodermal bands which effected the asymmetrical disruptions. This theory was supported by the infrequency of anomalies in the affected fetus away from regions of surface disruption and its occurrence in families with inherited connective tissue disorders. ${ }^{20}$ It was suggested that the timing of amnion rupture might explain the wide variation of distribution and severity of abnormalities. ${ }^{3}$ More recent reviews have drawn attention to familial cases ${ }^{21}$ and the presence of internal structural defects, some of which might be explained by vascular disruption $^{22}$ and suggest that amniotic bands are a late event in the process. It is important to note that physical manipulation of the gestational sac during chorionic villus sampling can produce vascular disruption in the embryo. ${ }^{23}$ Lockwood et $a^{24}$ suggested that amniotic bands are always secondary and may complicate embryonic or fetal disruption from any cause provided that it affects cutaneous integrity. Donnai and Winter ${ }^{25}$ moved back towards Streeter ${ }^{1}$ and postulated that a human homologue of the mouse mutant disorganisation (DS) gene might explain some cases of amniotic disruption, drawing parallels between abnormalities observed in these mice and some of the human fetuses. This mouse model exhibits both asymmetrical limb defects and exencephaly, ${ }^{26-28}$ while complex hamartomas are frequently present both close to the body surface and within body cavities. Lower genitourinary malformations are frequent and thoracoschisis and gastroschisis are occasional findings. Hummel ${ }^{27}$ gives no indication of the number of animals with multiple abnormalities, although this is clearly seen from her illustrations. In the more recent study ${ }^{28}$ the majority $(88.5 \%)$ of abnormal mice had only a single anomaly, $10 \%$ had two, and $1.4 \%$ had three separate anomalies, whereas multiple defects involving different body areas are usual in human ARS. The disorganisation mutation model would be more convincing if familial cases, in the absence of conditions which might be expected to predispose to amnion rupture, were observed more frequently. Bamforth ${ }^{29}$ also supported Streeter ${ }^{1}$ and suggested that the abnormal neuropore closure and consequent errors in migration of cephalic neural crest tissue explain most of the observed defects. Mo-
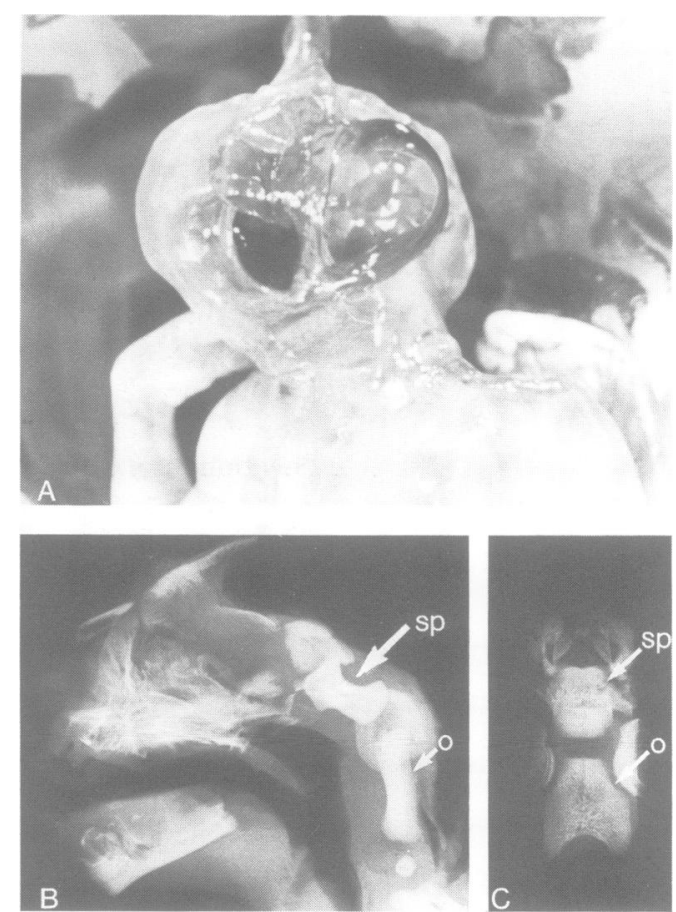

Figure 10 Human fetus with amnion rupture sequence. Gestational age 22 weeks. (A) Appearance of neck. (B) Lateral radiograph of axial midsagittal segment of cranial components. The basilar part of the occipital bone $(0)$ and the postsphenoid bone (sp) appear normal. (c) Frontal radiograph of postsphenoid bone (sp) and occipital bone (o) shown in $B$. The radiographs indicate that this is a normal human fetus secondarily affected by amnion rupture sequence. 
ermann et $\mathrm{al}^{30}$ considered that the Streeter ${ }^{1}$ and Torpin $^{2}$ theories are not mutually exclusive, that confusion has been compounded by lumping together the more severe defects, best explained by Streeter based hypotheses and the localised, often peripheral disruptions which are more likely to result from local amnion disruption, ${ }^{2}$ just because both groups involve adherence to placental membranes. Yang ${ }^{31}$ had observed the same confusion and suggested that cases of limb-body wall complex be removed from consideration of amnion rupture sequence. He suggested that histological examination of the placenta enabled the distinction to be made.

Systematic mapping of the axial skeletal components in fetuses with amnion rupture sequence, as performed in the present investigation, does not seem to have been carried out before. The axial skeletal tissue is assumed to reflect the condition of the notochord, known to be involved in neural tube closure and also in the formation of sclerodermal tissue. ${ }^{32}$ Thus, radiography of the axial skeleton seems valuable in evaluating anencephalic conditions resulting from malfunction of the notochord.

The method described seems also to be valid in timing the onset of malformation, since a fetus with a normal spine has inevitably been exposed to amniotic band disturbance in the axial skeleton later than a fetus with types of malformations such as double vertebral bodies (without ossification in the notochord region), which can be traced back to the very early failure in notochordal induction of the para-axial scleroderm. This condition cannot arise later, after the vertebral bodies have been formed normally by bone encircling the notochord.

Timing has been recognised as an important element in evaluating the pathogenesis. ${ }^{3213334} \mathrm{It}$ is generally agreed that the earlier the amniotic bands form during gestation, the greater the likelihood of associated abnormalities. In the present report, it is obvious that the latest event to interfere with fetal craniofacial development must be the one in the fetus illustrated in fig 10. In this case it is to be supposed that the sphenoid bone had formed normally, before disruption. This is not the case in fig 9 , where development of the sphenoid bone is abnormal. This bone normally forms at 14 weeks of gestation, which is later than the onset of ossification of the occipital bone. ${ }^{161719}$ The disruption of craniofacial bones is also dependent on local interactions.

Further studies of the axial skeleton in amnion rupture sequence fetuses with cranial involvement are needed to confirm the findings of this small study. It is important in genetic counselling to be able to distinguish primary anencephaly from secondary disruption. ${ }^{4}$ We suggest that analysis of the axial skeleton be included in the diagnostic examination of amnion rupture fetuses. The observations of Donnai and Winter, ${ }^{25}$ and the observation of familial cases $^{21}$ and internal malformations ${ }^{22}$ underline the need for detailed fetal examination and careful history taking and a more cautious approach to parental counselling than has perhaps been the case in the recent past.
This investigation was supported by grants 12-9762, 12-0405, This investigation was supported by grants $12-9762,12-0405$, by grants from the Danish Dental Association (FUT).

1 Streeter GL. Focal deficiencies in fetal tissues and their relation to intrauterine amputations. Contrib Embryol Carnegie Inst 1930;22:1-44.

2 Torpin R. Amniochorionic mesoblastic fibrous strings and amnionic bands. Am $\mathcal{f}$ Obstet Gynecol 1965;91:65-75.

3 Higginbottom MC, Jones KL, Hall BD, Smith DW. The amniotic band disruption complex: timing of amniotic rupture and variable spectra of consequent defects. $\mathcal{F}$ rupture and variable spe

4 Keeling JW, Boyd PA. Congenital malformations, prenatal diagnosis and fetal examination. In: Keeling JW, ed. Fetal and neonatal pathology. 2nd ed. Chapter 4. London: Springer-Verlag, 1993

5 Seeds JW, Cefalo RC, Herbert WNP. Amniotic band syndrome. Am $\mathcal{F}$ Obstet Gynecol 1982;144:243-8.

6 Hughes RM, Benzie RJ. Amniotic band syndrome causing fetal head deformity. Prenat Diagn 1984;4:447-50.

7 Urich $\mathrm{H}$, Herrick MK. The amniotic band syndrome as a cause of anencephaly. Report of a case. Acta Neuropathol 1985;67:190-4.

8 Goldstein RB, Filly RA. Prenatal diagnosis of anencephaly: spectrum of sonographic appearances and distinction from the amniotic band syndrome. Am $\mathcal{F}$ Roentgenol 1988;151: 547-50.

9 Harrington BJ, Horger EO, Edwards JG. A counseling dilemma involving anencephaly, acrania and amniotic bands. Genet Counsel 1992;3:183-6.

$10 \mathrm{Kjær}$ I, Keeling JW, Graem N. The midline maxillofacial skeleton in human anencephalic fetuses. Cleft Palate skeleton in human anen
Craniofac $\mathcal{f} 1994 ; 31: 250-6$.

11 Kjær I, Keeling JW, Graem N. Cranial base and vertebral column in human anencephalic fetuses. $\mathcal{f}$ Craniofac Genet Dev Biol (in press).

$12 \mathrm{Kjær}$ I. Skeletal maturation of the human fetus assessed radiographically on the basis of ossification sequences in the hand and foot. Am F Phys Anthropol 1974;40:257-76.

$13 \mathrm{Kjær}$ I, Graem N. Simple autopsy method for analysis of complex fetal cranial malformations. Pediatr Pathol 1990; 10:717-27.

14 Kjær I, Kjær TW, Graem N. Ossification sequence of occipital bone and vertebrae in human fetuses. $\mathcal{f}$ Craniofac Genet Dev Biol 1993;13:83-8.

$15 \mathrm{Kjær}$ I. Prenatal skeletal maturation of the human maxilla. 7 Craniofac Genet Dev Biol 1989;9:257-64.

$16 \mathrm{Kjær}$ I. Radiographic determination of prenatal basicranial ossification. 7 Craniofac Genet Dev Biol 1990;10:113-23.

$17 \mathrm{Kjær}$ I. Ossification of the human fetal basicranium. $f$ Craniofac Genet Dev Biol 1990;10:29-38.

$18 \mathrm{Kjær}$ I. Prenatal human cranial development evaluated on coronal plane radiographs. F Craniofac Genet Dev Biol 1990;10:339-51.

$19 \mathrm{Kjær}$ I. New methods of analyzing bone growth and bone maturation of the human fetal cranium. In: Dixon $A D$, maturation of the human fetal cranium. In: Dixon AD, methodology and applications. Boca Raton: CRC Press, methodology and

20 Young ID, Lindenbaum RH, Thompson EM, Pembrey ME. Amniotic bands in connective tissue disorders. Arch Dis Child 1985;60:1061-3.

21 Hunter AGW. Carpenter BF. Implications of malformations not due to amniotic bands in the amniotic band sequence. Am $\mathcal{F}$ Med Genet 1986;24:691-700.

22 Van Allen MI, Curry C, Gallagher L. Limb body wall complex. I. Pathogenesis. Am $\mathcal{F}$ Med Genet 1987;28:529-48.

23 Quintero RA, Romero R, Mahoney MJ, Vecchio M, Holden J, Hobbins J. Fetal haemorrhagic lesions after chorionic villous sampling. Lancet 1992;339:193.

24 Lockwood C, Ghidini A, Romero R, Hobbins JC. Amniotic band syndrome: reevaluation of its pathogenesis. $A m \mathcal{F}$ Obstet Gynecol 1989;160:1030-3.

25 Donnai D, Winter RM. Disorganisation: a model for 'early amnion rupture'? I Med Genet 1989;26:421-5.

26 Hummel KP. The inheritance and expression of disorganization, an unusual mutation in the mouse. $\mathcal{F}$ Exp Zool 1985;137:389-423.

27 Hummel KP. Developmental anomalies in mice resulting from action of the gene, disorganisation, a semi-dominant lethal. Pediatrics 1959;23:212-21.

28 Crosby JL, Varnum DS, Nadeau JH. Two-hit model for sporadic congenital anomalies in mice with the disorganization mutation. Am $\mathcal{f}$ Hum Genet 1993;52:866-74

29 Bamforth JS. Amniotic band sequence: Streeter's hypothesis reexamined. Am $\mathcal{F}$ Med Genet 1992;44:280-7.

30 Moerman P, Fryns JP, Vandenberghe K, Lauweryns JM. Constrictive amniotic bands, amniotic adhesions, and limbbody wall complex: discrete disruption sequences with pathogenetic overlap. Am $\mathcal{F}$ Med Genet 1992;42:470-9.

31 Yang SS, ADAM sequence and innocent amniotic band: manifestations of early amnion rupture. Am $\mathcal{F}$ Med Genet 1990;37:562-8.

$32 \mathrm{Kjær} \mathrm{I}$. The prenatal axial skeleton as marker of normal and pathological development of the human central nervous lesions in the newborn. Hypoxic and haemodynamic palesions in the newborn. Hypoxic and haemodynamic
thogenesis. Copenhagen: Munksgaard, 1994: 124-35.

thogenesis. Copenhagen: Munksgaard, 1994: 124-35.
33 Heifetz SA. Strangulation of the umbilical cord by amniotic bands: report of 6 cases and literature review. Pediatr Pathol 1984;2:285-304

34 Miller MT, Deutsch TA, Cronin C, Keys CL. Amniotic bands as a cause of ocular anomalies. Am $\mathcal{f}$ Ophthalmol 1987;104:270-9. 